\title{
WIRTBARKEIT: COSMOPOLITAN RIGHT AND INNKEEPING
}

\author{
Aravind Ganesh* (D) \\ Max Planck Institute Luxembourg for \\ Procedural Law and Vrije Universiteit Amsterdam
}

\begin{abstract}
After defining Cosmopolitan Right as being limited to the conditions of "hospitality," Kant includes "Wirtbarkeit" in brackets, a word that connotes innkeeping. Moreover, significant similarities obtain between the relevant passages of the Perpetual Peace and those of the Digest of Justinian on the obligations of ships' masters, innkeepers, and stable keepers. Unlike for ordinary householders, hospitality for innkeepers is a legal obligation, not a matter of philanthropy: they have traditionally been deemed public officials with limited discretion to refuse travelers, and as fiduciaries of their guests strictly liable for losses to their property. This article attempts to explain Kant's concept of Cosmopolitan Right by analogy to the private law of innkeeping, and ultimately engages in the central philosophical debate about Cosmopolitan Right by accounting for Cosmopolitan Right solely from the "innate" right to freedom, rather than from "acquired" facts such as land or resource distributions or historical injustices.
\end{abstract}

After introducing it under the caption "Cosmopolitan right shall be limited to conditions of universal hospitality," Kant begins his discussion of the Third Definitive Article to the Perpetual Peace with the following comments:

Here, as in the preceding articles, it is not a question of philanthropy but of right, so that hospitality (hospitableness) [Hospitalität (Wirtbarkeit)] means the right of a foreigner not to be treated with hostility because he has arrived on the land of another. The other can turn him away, if this can be done without destroying him, but as long as he behaves peaceably where he is [auf seinem Platz], he cannot be treated with hostility. What he can claim is not the right to be a guest [Gastrecht] (for this a special beneficent pact would be required,

* I am grateful to Philip Allott, Claudio Corradetti, Ester Herlin-Karnell, Emily Kidd White, Mattias Kumm, Peter Niesen, André Nunes Chaïb, Madeline Gleeson, Alice Pinheiro Walla, Arthur Ripstein, Enzo Rossi, Christof Royer, Hélène Ruiz Fabri, Konstanze von Schütz, Edoardo Stoppioni, Ernest Weinrib, and Reinhard Zimmermann. I am strictly and vicariously liable for all mistakes. 
making him a member of the household [Hausgenossen] for a certain time), but the right to visit $[$ Besuchsrecht $] ..{ }^{1}$

Although it does not feature in the later Doctrine of Right, the concept of hospitality has nonetheless given rise to a small cottage industry. This is in part because of the contrast between the "enigmatic" fashion of its description and its "obvious centrality" to Kant's general theory of law, ${ }^{2}$ and because of the pressing need for a moral response to the massive waves of migration produced by contemporary globalization. Amid the large amount of ink spilled on the topic, one thing has mostly escaped comment: the word Wirtbarkeit, included in parentheses for elucidation. This paper argues that Kant is referring to innkeeping, such that cosmopolitan right and the corresponding obligations of receiving states may be explained to some extent by analogy to the law of innkeeping.

Section I begins by arguing that popular interpretations of the concept of hospitality as "welcome" are incompatible with Kant's fundamental commitments in his practical philosophy. Section II returns to the passage from the Third Definitive Article, and demonstrates the textual parallels with the titles of the Digest of Justinian concerning the obligations of innkeepers. It then briefly summarizes the history of the law of innkeeping, from which certain themes arise that will be relevant to the later theoretical discussion. Section III sketches out the basic structure of Kant's legal philosophy as expressed in the Doctrine of Right. Finally, Section IV builds on previous sections to stake a position in the central debate surrounding the nature of cosmopolitan right. It argues that cosmopolitan right arises exclusively from the innate right to freedom, rather than from an "acquired" entitlement to equal distributive shares of the earth's resources, or from a right to be somewhere. Similarly, a receiving state's cosmopolitan obligation arises simply from its status as a public person, and not from any kind of proprietorship over sections of the earth's surface.

Some final caveats. Neither the discussion of the legal history of innkeeping nor the use of the language of modeling or analogy are meant to suggest that Kant constructs cosmopolitan right through a sort of Dworkinian, interpretive rationalization of the positive legal practices he saw around him. Rather, the legal commonplaces he calls on in his writings are not used as evidence, much less as justifications, but as illustrations of his theoretical claims. The same applies here. References are made interchangeably

1. Immanuel Kant, Toward Perpetual Peace, in Practical Philosophy: The Cambridge Edition of the Works of Immanuel Kant 311, 328-329 (8:357-358) (Mary J. Gregor ed., Cambridge Univ. Press, 9th ed. 2006) (1795). Citations to the Doctrine of Right and the Perpetual Peace are denoted with " $D R$ " and " $P P$ " respectively and cite the page numbers of the Akademie compilation of Kant's collected works, and of Mary Gregor's translation. The preparatory draft for the Perpetual Peace, cited as "DPP," is available online at the Korpora database maintained by the universities of Duisburg and Essen.

2. Peter Niesen, Colonialism and Hospitality, 3 Pol. \& Eтнісs Rev. 90, 90 (2007). 
to Roman and English law because the common law of bailment is almost wholly civilian in origin, ${ }^{3}$ with the law of innkeeping having had a particularly close parallel development between England and the continent. ${ }^{4}$

\section{HOSPITALITY AS WELCOME-SOME PROBLEMS}

Translated into English, the string "hospitality (hospitableness)" seems tautological: the word in the brackets does nothing to explain the italicized technical term preceding it. Nevertheless, Mary Gregor's editorial decision is understandable. "Hospitality" sounds like the ethical sensibility shown by hosts to guests, ${ }^{5}$ and this intuition seems to be confirmed by the fact that "Wirtbar" is defined in Grimm's Dictionary as an early eighteenth-century poetic expression for "gastlich, einladend, freundlich." Jacques Derrida, one of the very few writers to pay attention to the word Wirtbarkeit, offers a similar interpretation:

Wirt ... is at the same time the patron and the host [hotte], the host who receives the Gast, the Gastgeber, the patron of a hotel or restaurant. Wirtlich, like gastlich, means "hospitable", "welcoming." Wirtshaus is the café, the cabaret, the inn, the place that accommodates. And Wirt governs the whole lexicon of Wirtschaft, which is to say, economy and, thus, oikonomia, law of the household. ${ }^{7}$

Likewise, Sarah Holtman interprets cosmopolitan right as connoting certain "social graces" of civility and hospitality, which may be thought of "as at

3. See Coggs v. Bernard, 92 Eng. Rep. 107, 109-114 (1703); William Jones, An Essay on the LAW OF BaILMENTs (London, Dilly, 1781), at 11, 35-41, 75-77. Story criticizes Jones's "extreme solicitude to make the principles of this branch of jurisprudence, as administered at Rome, appear in harmony with the common law, as administered in Westminster Hall," but concedes that Lord Holt's reasoning in Coggs v. Bernard "was greatly assisted by Bracton, and still more by the civil law, from which Bracton had drawn his own materials." JosEPH STORY, Commentaries on the Law of Bailments: With Illustrations from the Civil and the Foreign Law (Cambridge, Hilliard \& Brown 1839), at iv-v. Holmes in contrast contends that English bailment remains fundamentally Germanic. Oliver Wendell Holmes, The Common LaW (Harv. Univ. Press, 2009) (1881), at ch. 5.

4. Reinhard Zimmermann, Innkeepers' Liability - Die Entwicklung der Gastwirtshaftung in England, in Festschrift für Claus-Wilhelm Canaris zum 70. Geburtstag (Volume 2) 1435, 1437 (Andreas Heldrich, Jürgen Prölss \& Ingo Koller eds., 2007) ("Interessant ist die Gastwirtshaftung auch als Zeugnis europäischer Rechtseinheit - sowohl historisch begründeter als auch durch moderne Maßnahmen der Privatrechtsharmonisierung jedenfalls teilweise wiederlangter.”).

5. See Sarah Holtman, Civility and Hospitality: Justice and Social Grace in Trying Times, 6 Kantian Rev. 85, 100 (2002) ("[W] e often do think of those to whom we ascribe hospitality as having developed a set of appropriately welcoming practices towards strangers. . . We may attribute hospitality to the person who always seems to know just the way to make a stranger, whether the new colleague or the international visitor, feel welcome."); Paul Formosa, Kant on the Highest Moral-Physical Good: The Social Aspect of Kant's Moral Philosophy, 15 Kantian Rev. 1, 11 (2010) ("To be hospitable is to invite the other into your home or country, to share your food and table, and to enter into peaceful social relations with him based on the respect and love due to all humans, wherever they come from.").

6. Grimm's DictionarY, available at http://dwb.uni-trier.de/de/.

7. Jacques Derrida, Hostipitality, 5 Angelaki 3, 4 (2000). 
once signs of, and helpmates to, moral virtue, which for the Kantian is itself a helpmate to justice," ${ }^{8}$ while Seyla Benhabib remarks that it is "unclear ... whether such relations among peoples and nations involve acts of supererogation, going beyond the call of moral duty. ..." In a series of dialogues with Jürgen Habermas following the September 2001 attacks, Derrida similarly describes hospitality as almost like courage:

Pure and unconditional hospitality, hospitality itself, opens or is in advance open to someone who is neither expected nor invited ... The visit might actually be very dangerous, and we must not ignore this fact, but would a hospitality without risk, a hospitality backed by certain assurances, a hospitality protected by an immune system against the wholly other, be true hospitality? ${ }^{10}$

For such reasons, Derrida concludes that the Kantian hospitality is hopelessly contradictory; it envisages the reception of the visitor only "on the condition that the host, the Wirt . . maintains his own authority in his own home ... thereby affirm(ing) the law of hospitality as the law of the household, oikonomia, the law of his household, the law of a place (house, hotel, hospital, hospice, family, city, nation, language, etc.) ..."11 Likewise, Benhabib considers that the concept of cosmopolitan rights of asylum suffers from a fundamental confusion as to whether they are legally enforceable norms or merely "reciprocal moral obligations" that states are not compelled to recognize. ${ }^{12}$

The first problem with such interpretations, and why they end in contradiction, is that they ignore Kant's warning that he is talking about rights and not philanthropy. He reiterates this point in the Doctrine of Right, which states that cosmopolitan right is not "a philanthropic (ethical) principle but a principle having to do with rights." ${ }^{13}$ In fact, this distinction between right and virtue constitutes the core of Kant's practical philosophy. As a fundamental matter, law has nothing to do with the advancement of virtue, because acts purporting to fulfill duties of virtue are worthless unless done purely for the sake of the moral end. A shopkeeper does not fulfill any duties of virtue if he deals honestly with his customers only in order to retain their long-term patronage. Likewise, laws compelling honesty on pain of sanction do nothing to advance the virtue of honesty, because any resulting honest dealing would be for the sake of complying with the law rather than for the sake of honesty itself. Simply put, a legal obligation of welcome does not make sense; you cannot feel welcome if your host is

8. Holtman, supra note 5, at 4.

9. Seyla Benhabib, The Rights of Others: Aliens, Residents, and Citizens (2004), at 28.

10. Giovanna Borradori, Philosophy in a Time of Terror: Dialogues with Jürgen Habermas and JaCQUeS DeRriDa (2013), at 128-129.

11. Derrida, supra note 7 , at 4 .

12. BenhabiB, supra note 9 , at 29.

13. DR 6:352, 489. Recht can mean both "law" and "right," in the sense of both an entitlement as well as a correct state of affairs. 
legally required to be nice to you. The idea of welcome is conceivable only because hosts are allowed to be awful to their guests.

Instead, the sole principle structuring right is the idea of "external freedom"; that is, the ability to make choices with the means at your disposal in a manner compatible with a like ability on the part of all other persons to do the same. ${ }^{14}$ In contrast to virtue, all that is needed to fulfill duties of right is compliance with forms of interaction compatible with all persons making choices for themselves using the means they rightfully have. Whether or not the substance of a choice is ethically commendable is a separate and subsequent question. This why the Doctrine of Right comes before the Doctrine of Virtue: for Kant, one must first envisage the conditions under which freedom is assured for all persons forever-peace. Only then can we begin to talk about how to be a good person, because unless you are free, your choices are not yours to be praised or blamed for. This basic idea is illustrated by the remark that cosmopolitan right is simply the "rational idea of a peaceful, even if not friendly, thoroughgoing community of all nations on the earth. . ."15 Peace is made between enemies, not friends. Afterward, they may go on to become friends, or they may not. Only after peace is conceived of is it worthwhile or even possible to think about friendliness, civility, or other supererogatory social graces between nations. Justice is the helpmate to virtue, not the other way round.

The second problem is that the reliance on the figure of a master of a household is difficult to reconcile with the general distinction between private and public law. Admittedly, Kant often likens states to parents, for instance when he observes that

\footnotetext{
As natives of a country, those who constitute a nation can be looked upon analogously to descendants of the same ancestors (congeniti) even though they are not. Yet in an intellectual sense and from the perspective of rights, since they are born of the same mother (the republic) they constitute as it were one family (gens, natio).... ${ }^{16}$
}

This comparison, however, only emphasizes the difference between the republic and a private household. The former envisages a materfamilias "in an intellectual sense," but contrary to Derrida, there is no official language, religion, or ethnicity in her household. Accordingly, Derrida's notion of the "laws of a household" is un-Kantian insofar as it assumes the preservation of ethnic, religious, or cultural bonds to be a proper state function. ${ }^{17}$

14. DR 6:230, 387. This principle is designated as the "Universal Principle of Right."

15. DR 6:352, 489 .

16. DR $6: 343,482$.

17. See $D R 6: 327,469$ (arguing that for a sovereign to establish an official religion would be "beneath its dignity," because thereby "the monarch makes himself a priest"); BENHABIB, supra note 9 , at 81 : 
Thirdly, to imagine that Kantian cosmopolitan right imposes a duty to welcome visitors, or to criticize it as othering and exclusionary of them, is to gloss over his deep and persistent opposition to European colonialism and imperialism. ${ }^{18}$ One of the crueler ironies of history is that the figure of the refugee played a central role in justifying those projects. Consider that Grotius begins the Free Sea-a legal opinion commissioned by the Dutch East India Company-with a lamentation:

What men, what monsters, what inhuman race,

What laws, what barbarous customs of the place,

Shut up a desert shore to drowning men,

And drive us to the cruel seas again? ${ }^{19}$

Vitoria had earlier used these same lines from the Aeneid to defend the Spanish conquest of the Native Americans as a just war. ${ }^{20}$ In fact, refugees play an increasingly marginal role as Kant develops the concept of cosmopolitan right: the Draft for the Perpetual Peace mentions shipwreck victims and sailors caught in storms in passing as having rights of refuge, ${ }^{21}$ these specific examples are omitted in the final version, and the Doctrine of Right does not mention them at all. In contrast, the critique of colonialism becomes increasingly prominent. Kant devotes more than a page to this topic in the Draft, $^{22}$ and includes a blistering passage in the published version, in which he takes note of the curious fact that European trading companies in the Sugar Islands were constantly teetering on the brink of insolvency despite practicing the "cruelest and most calculated slavery" there. Given their abject failure as commercial enterprises, Kant speculates that their real function was to train sailors for wars back home in Europe on behalf of princes who made "much ado of their piety . . . while they drink wrongfulness like water. . .."23 Finally, the section on Cosmopolitan Right in the Doctrine of Right is almost entirely a critique of European settlement and colonization.

Kant does not just condemn the enslavement of colonized peoples as wrongful; he also emphasizes the corruption this brings on the colonizing

To view peoples as homogeneous entities characterized by a clearly identifiable 'moral nature' and a source of 'common sympathies' is not only sociologically wrong; this view is inimical to the interests of those who have been excluded from the people because they refuse to accept or respect its hegemonic moral code.

18. See Niesen, supra note 2 , at 91.

19. Hugo Grotius, The Freedom of the Seas, or, The Right Which Belongs to the Dutch to Take Part in the East Indian Trade (James Brown Scott ed., Ralph van Deman Magoffin trans., Lawbook Exchange, 2001) (1609), at 8.

20. Francisco de Vitoria, On the American Indians, in Vitoria: Political Writings 231, 278 (Anthony Pagden \& Jeremy Lawrance eds., Cambridge Univ. Press, 1991) (c. 1532).

21. DPP 23:173.

22. DPP 23:174-175.

23. $P P$ 8:359, 330 . 
state. This same claim was expressed powerfully by one of his contemporaries in the course of what may have been the first campaign in history to prosecute a multinational corporation for extraterritorial human rights violations:

In India all the vices operate by which sudden fortune is acquired; in England are often displayed, by the same persons, the virtues which dispense hereditary wealth. . . . They marry into your families; they enter into your senate; they ease your estates by loans . . . there is scarcely a house in the kingdom that does not feel some concern and interest, that makes all reform of our eastern government appear officious and disgusting; and, on the whole, a most discouraging attempt. ${ }^{24}$

This is what Kant means when he says that "a violation of right on one place of the earth is felt in all. ..." Kant's statement is not, as might be imagined, intended as a justification for humanitarian interventions or the "responsibility to protect." Instead, it is a warning that colonialism always corrupts the colonizer. The corresponding sentence in the Draft is emphatic about this: it speaks of faraway atrocities that ultimately set the mother country ablaze with war. ${ }^{26}$ Kant's "poor and minimal" ${ }^{27}$ definition of cosmopolitan right is not a bug in his legal-political theory; it is the feature. It permits a clean break from earlier writers who, by formulating thick rights to visit, trade, and proselytize, effectively supplied the intellectual foundations for European colonialism, and thus the conditions for endless war.

For these reasons, Hospitalität cannot mean "hospitableness," as Mary Gregor translates it, but must have legal significance. In this regard, however, Derrida might nevertheless be on to something. Recall his observation that Wirtbarkeit is also suggestive of "the café, the cabaret, the inn. . .."

\section{HOSPITALITY AND THE LAW OF INNKEEPING}

Of the 432 titles of the Digest of Justinian, two deal with the obligations of innkeepers, alongside those of ships' masters and keepers of stables. Consider the passage by Ulpian on the "Action for Theft Against Ships' Masters, Innkeepers, and Liverymen," or furti adversus nautas caupones stabularios:

24. Edmund Burke, Mr. Burke's Speech on Mr. Fox’s East India Bill (Dublin, White 1784), at 32-33.

25. $P P$ 8:360, 330 .

26. DPP 23:175 ("Ein Funke der Verletzung des Menschenrechts auch in einem andern Welttheil gefallen nach der Brennbarkeit des Stoffs der Herrschsucht in der menschlichen Natur vornehmlich ihrer Häupter die Flamme des Krieges leicht bis zu der Gegend verbreitet wo er seinen Ursprung genommen.").

27. Pavlos Eleftheriadis, Cosmopolitan Law, 9 Eur. L.J. 241, 245 (2003). Instead, Kant was concerned that his understanding of cosmopolitan right would seem "fantastic and exaggerated." PP 8:360, 330 . 
The innkeeper is answerable for the deeds of those whom he has in the inn to run the establishment as also of those who reside in the inn; he is not answerable for the acts of passing travellers. For an innkeeper or liveryman is not regarded as choosing his own traveller and cannot refuse those making a journey; but in a way, the innkeeper does select his permanent residents, since he does not reject them, and so should be answerable for what they do. ${ }^{28}$ (emphasis added)

Ulpian's distinction between passing travelers, whom the innkeeper cannot refuse, and permanent residents, whom the innkeeper does select, seems to foreshadow Kant's contrast between the "right to visit," which a receiving state cannot refuse, and the "right to be a guest," which requires a "special beneficent pact." Moreover, the innkeeper's inability to refuse travelers seems mirrored in a receiving state's obligation under cosmopolitan right to take in visitors who will be destroyed if turned away.

There is, of course, an obvious difference. Kant's obligation to receive arises only if turning the visitor away would result in her destruction; in all other cases, a state's cosmopolitan obligation is only to refrain from treating visitors with hostility. Except for this one case, states have full discretion to turn visitors away. The parallel to this is in the other title of the Digest on innkeepers-the "Action for Receipt" or receptum nautarum cauponum stabulariorum - where the same jurist Ulpian, in apparent contradiction to his commentary on the actio furti, comments that:

The praetor says: "I will give an action against seamen, innkeepers, and stablekeepers in respect of what they have received and undertaken to keep safe, unless they restore it." This edict is of the greatest benefit, because it is necessary generally to trust these persons and deliver property into their custody. Let no one think that the obligation placed on them is too strict; for it is in their own discretion whether to receive anyone, and unless this provision were laid down, there would be given the means for conspiring with thieves against those whom they receive, since even now they do not refrain from mischief of this kind. ${ }^{29}$ (emphasis added)

\section{A. Innkeeping-A Short Legal History}

This section provides a brief background and history of the law of innkeeping, from which certain themes emerge that will be relevant for subsequent theoretical discussion. These are, first, that innkeepers are fiduciaries of their guests; and second, that they are public officials. The actio furti is codified in the Institutes as one of the four quasi-delictual obligations; that is,

28. Dig. 47.5.1.6 (Ulpian, ad Edictum 38), trans. Alan Watson, 4 The Digest of Justinian 275 (rev. ed. 1998).

29. Dig. 4.9.1 pr - 1 (Ulpian, ad Edictum 14), trans. Alan Watson, 1 The Digest of Justinian 160 (rev. ed. 1998). 
obligations arising "as if" by delict. ${ }^{30}$ It is not a delict proper, because whereas delictual liability always requires fault or intention, liability under the actio furti is strict. The actio de recepto is not categorized as a quasi-obligation, presumably because it requires an underlying contract of carriage, lodging, or stabling. ${ }^{31}$ Nevertheless, an innkeeper's receptum liability also cannot be explained purely as a matter of contract or delict. In fact, the actio furti and the actio de recepto constitute vanishingly rare examples of strict or vicarious liability in Roman law. ${ }^{32}$ If you transfer cloth to a tailor that then is destroyed or goes missing, you can sue in contract for failure to make the shirt, and in delict after proving fault. In contrast, innkeepers' liability arises the instant the chattels are taken into custody, and cannot be avoided even by express refusal to take care of the goods. ${ }^{33}$

As indicated by Ulpian's commentary to the actio de recepto, the peculiar historical reasons why innkeepers were treated so harshly had something to do with social snobbery. A Roman inn or caupona was little more than a brothel, ${ }^{34}$ and its "reputation was so bad that it was regarded as degrading for a senator to lunch or dine in a caupona." ${ }^{35}$ Not surprisingly, people operating such businesses were so unsavory that their guests were seen as in need of particularly solicitous legal protection even (or perhaps especially) if they were accommodated for free. The rediscovery of the Roman law in the eleventh century transposed these idiosyncracies of Roman social life on an entirely different medieval context, a crucial aspect of which was the proliferation of intracontinental travel for pilgrimage following the end of the Black Death. From the early thirteenth century, English law required innkeepers to provide surety for the good behavior of foreign travelers, meaning that innkeepers had to be "good and sufficient persons"- a far cry from the Roman caupo ${ }^{36}$ In 1563, a French royal ordinance explicitly prohibited innkeepers from refusing travelers without cause, the purpose of which, according to David Bogen, was not so much aimed at ensuring accommodation for travelers, but at enforcing a public purpose of setting prices for meals at inns and taverns. ${ }^{37}$ Nevertheless, the official duty evolved around the same time into privately enforceable legal obligation. In England, this

30. J. Inst. 4.5.3.

31. Reinhard Zimmermann, The Law of Obligations: Roman Foundations of the Civilian Tradition (1996), at 517.

32. See Peter Birks, The Roman Law of Obligations: The Collected Papers of Peter Birks (Eric Descheemaeker ed., 2014), at 213; Holmes, supra note 3, at 16-17; Zimmermann, supra note 31, at 1121-1122.

33. JonEs, supra note 3, at 95; STORY, supra note 3, at 307 ( $\$ 470)$.

34. Reinhard Zimmermann, Die Geschichte der Gastwirtshaftung in Deutschland, in Usus modernus pandectarum: Römisches Recht, Deutsches Recht und Naturrecht in der Frühen Neuzeit; Klaus Luig zum 70. Geburtstag 271, 274 (Hans-Peter Haferkamp \& Tilman Repgen eds., 2007).

35. Zimmermann, supra note 31 , at 516, n.51.

36. David S. Bogen, The Innkeeper's Tale: The Legal Development of a Public Calling, 1996 Uтан L. REv. 51, 60-61 (1996).

37. See id. at 84 , and sources cited therein. 
was first recognized in White's Case, where the Court of Common Pleas recognized an "action on the case" or claim for loss against an innkeeper who turned a guest away despite having room. ${ }^{38}$

It must be emphasized that the obligation to take all comers was a wholly modern development; the law that controlled in Rome was, as provided for in the actio de recepto, that innkeepers could refuse guests at will. ${ }^{39}$ Although this was a matter of common knowledge, jurists nevertheless attempted to ground the modern practice on the old Roman jurists by denigrating Ulpian's remarks about the actio de recepto in favor of those concerning the actio furti. The strategies ranged from speculating that the actio de recepto was incorrectly transcribed during the compilation of the Digest to interpreting the discretion referred to in it as about entering the profession rather than about receiving individual travelers. ${ }^{40}$ In any event, by Kant's time, it was trite that innkeepers and other common carriers exercised a uniquely public employment, such that they were not free to refuse guests who could afford a reasonable sum for their lodgings. ${ }^{41}$

Notwithstanding innkeepers' vastly improved social prestige, and their new onerous public duties, the ancient rule of the strict liability of innkeepers for damage or loss to guest property remained in place, and is in fact still good law to this day. ${ }^{42}$ For a while, Ulpian's old "innkeeper-as-scumbag" theory proved remarkably resilient in justifying this situation, even though it had long ceased to be convincing as a description of the hotel business, let alone of other common carriers. ${ }^{43}$ The shift to a different, fiduciary rationale is apparent from Sir William Jones's groundbreaking essay on the English law of bailment:

For travellers, who must be numerous in a rich and commercial country, are obliged to rely almost implicitly on the good faith of innholders, whose

38. White's Case, 73 Eng. Rep. 343 (1558) (Eng.).

39. See StoRY, supra note 3 at 307 ( $\$ 470$ ) ("[B]y the common law (which in this respect differs from the civil law) an innkeeper is not, if he has suitable room, at liberty to refuse to receive a guest, who is ready to pay him a suitable compensation."). For reasons that cannot be explored here, it appears that the actio furti, much like the other quasi-delicts, became obsolete very early, perhaps even before the Digest was compiled. See Bogen, supra note 36, at 353-354.

40. See Bogen, supra note 36, at 355-357, and sources cited therein.

41. Coggs v. Bernard, 92 Eng. Rep., at 112 (defining a category of bailees as exercising "a publick employment," and who were by law required to "carry goods, against all events but acts of God, and of the enemies of the King"). A leading textbook on American innkeeping law observes that this "duty is symbolised by the traditional ceremony at the dedication of a new hotel or motel of throwing away a key to the inn, thus proclaiming to the world that the door to the hospitality of the inn will never be locked and that all weary travelers will always be welcome." John H. Sherry, The Laws of Innkeepers: For Hotels, Motels, Restaurants, and Clubs (John E. H. Sherry ed., 3d ed. 1993), at 39.

42. Subject to statutory limits, of course. See, e.g., Bürgerliches Gesetzbuch [BGB] [Civil Code], Aug. 18, 1896, §701; Hotel Proprietors Act, 1956, 4 \& 5 Eliz. 2, c. 62 , §1(2) (Eng.).

43. Zimmermann, supra note 31, at 521 ("Carriers by sea, innkeepers and stable keepers may, of course, still be individually unreliable; but it can hardly be maintained that in their collectivity, as members of the respective professions ...., they are particularly disreputable. After all, hotels without bawdyhouses are no longer that exceptional."). 
education and morals are usually none of the best, and who might have frequent opportunities of associating with ruffians and pilferers, while the injured guest could seldom or never obtain legal proof of such combinations, or even of their negligence, if no actual fraud had been committed by them. ${ }^{44}$

In contrast to Ulpian, Jones emphasizes the systematic vulnerability of the traveler-innkeeper relation: from the fact that travelers have no choice but to "trust these persons and deliver property into their custody," it follows that they are "obliged to rely almost implicitly on the good faith of innholders." The impossibility of proving negligence, let alone intent, means that guests and their "property are exposed to dangers emanating from a sphere which only the other party is able to organize and control." 45 The innkeeper is liable not because he is a scumbag, but because he is a fiduciary. ${ }^{46}$ In 1921, a South African innkeeper invoked the cessante ratione cessat lex maxim to argue that the rule on the strict liability of innkeepers had become obsolete. ${ }^{47}$ He lost.

Thus, the history of the law of innkeeping provides to some extent an illustration of what Kant calls "empirical" and "metaphysical" theories of law, as well as of his claim that empirical accounts are empty without a metaphysics. ${ }^{48}$ As a matter of empirical or "blackletter" legal history, the innkeeper's liability arose out of the professional disrepute of innkeepers. "Metaphysically" however, the innkeeper's liability can and must be expressed rationally as a fiduciary obligation arising from the systematic vulnerability inherent in the very form of the guest-innkeeper relation.

\section{PRIVATE LAW FOUNDATIONS OF KANT'S GENERAL THEORY OF LAW}

This section is intended to provide a synopsis of pertinent themes from Kant's theory of law. Readers already familiar with them may skip to the next section.

44. Jones, supra note 3, at 96. See also Zimmermann, supra note 31, at 516.

45. ZimmermanN, supra note 31, at 521. Zimmermann expresses this point in strikingly Kantian terms elsewhere. See Zimmermann, supra note 4, at 1435 ("Hätte [der Gast] ,regelmäßig den Beweis einer dem Gastwirthe zur Lastfallenden Verletzung einer kontraklichen Pflicht,' als Ursache für den eingetretenen Schaden zu führen, so wäre er weithin rechtlos.").

46. See, e.g., Paul B. Miller, A Theory of Fiduciary Liability, 56 McGILL L.J. 235, 278 (2010) (defining fiduciary relationships as those in which one person "exercises discretionary authority to set or pursue practical interests (including matters of personality, welfare or right) of another"); Frame v. Smith, [1987] 2 S.C.R. 99, II 60 (Can.) (Wilson J., dissenting) (defining a fiduciary relation as one where "(1) the fiduciary has scope for the exercise of some discretion or power; (2) the fiduciary can unilaterally exercise that power or discretion so as to affect the beneficiary's legal or practical interests; and (3) the beneficiary is peculiarly vulnerable to or at the mercy of the fiduciary holding the discretion or power").

47. Davis v. Lockstone 1921 A.D. 153, 159-160 (S. Afr.).

48. DR 6:229-230, 386-387. 
A. The Innate Right to Freedom and Its Expressions

In the Introduction to the Doctrine of Right, Kant defines rights in relational terms as "(moral) capacities to put others under obligations." ${ }^{\text {"9 }}$ Moreover, legal rights are "always connected with an authorization to use coercion." 50 That is to say, for a claim of right to be legal rather than ethical, it means that it is morally permissible to employ coercion against the addressee should she refuse it. Thereafter, the "highest division" of rights is between "innate" and "acquired" rights: an "innate right is that which belongs to everyone by nature, independently of any act that would establish a right," while "an acquired right is that for which such an act is required." there is only one innate right, or dignity inhering purely by virtue of being human: "independence from being constrained by another's choice ..." ."52

Kant's valuable insight here is that dignity does not consist in being supplied with things necessary for the satisfaction of interests or needs. A slave lacks dignity even if her master is extravagantly solicitous of her welfare because, formally, she remains an object at her master's mercy. As per another fundamental distinction, a person is "a subject whose actions can be imputed to him," while a thing is an "object of free choice" to which "nothing can be imputed." ${ }^{53}$ Being treated "rightly" as a person-that is, in accordance with one's nature as a person-means being recognized as subject to no laws other than those you give yourself, rather than as a thing at the disposal of others. For the same reason, neither can dignity consist in freedom understood in liberal terms as the ability to do whatever one wants to do without constraint, for this would just be a roundabout way of describing interest-satisfaction. The well-kept slave would lack dignity even if the kindly master told her she could do anything she liked and went on permanent holiday, for in formal terms she is no different than a dog let off its leash. If someone should assault her, she would have no means of lodging a complaint in her name, but would instead have to rely on her strength or hope for free persons such as her master or kindly passersby to intercede on her behalf.

This idea of an innate right to freedom can be expressed in a number of different ways. One such expression is the concept of "rightful honor," 54 which Kant reformulates the first of Ulpian's three precepts of law-honeste vivere — as a command to be a juridical person: "Do not make yourself a mere means for others but be at the same time an end for them." 55 Rightful honor does not mean that you cannot pursue shameful purposes, but only that you may not coherently do anything that effectively surrenders

49. DR 6:237, 393.

50. DR 6:231, 388.

51. DR 6:237, 393.

52. $I d$.

53. DR 6:223, 378.

54. DR 6:236, 392.

55. DR 6:236, 392 (referring to J. Inst. 1.1.3). 
your ability to set purposes. For instance, you cannot contract to enslave yourself, not because it would be disgraceful, but because it would be juridically nonsensical. Such a contract envisages you assuming an obligation to become a thing, which, by definition cannot have obligations. Any attempt to perform on it would therefore automatically release you from it. ${ }^{56}$ Another expression of innate right is something Kant calls the quality of being "beyond reproach." ${ }^{57}$ If another accuses you of wrong, they must prove it, not you. You can never be required to clear your own name. This basic case gives rise to one exceptional case: if someone wrongs you by spreading defamatory rumors about you, you do not need to prove the falsity of the rumor. Rather, the defendant has the burden of proving that her allegation is true. If the burdens were otherwise, you would potentially have to spend your entire life putting out any small fires others might see fit to start, thus rendering yourself a thing at the disposal of all others. A third way of expressing the innate right to freedom is as the "original common possession of the earth," and Kant grounds cosmopolitan rights to visit on this particular expression. We return to this in Section IV.

\section{B. Acquired Right, or Private Right}

The innate right to freedom gives rise to three kinds of "acquired" rights: "a right to a thing (ius reale), or a right against a person (ius personale), or a right to a person akin to a right to a thing (ius realiter personale), that is, possession (though not use) of another person as a thing." ${ }^{\text {5 }}$ This crucial passage can be explained as follows: a thing can potentially be both used and possessed at the same time. ${ }^{59}$ Your dignity lies in being treated as a person and not as a thing; that is, as mere means. As such, this does not mean that you cannot be possessed or used as means, but only that you cannot be possessed and used at the same time. From this arise three possible combinations of rights and obligations legitimately enforceable through coercion:

(1) Rights to things: These entitle one person to prevent all other persons from interfering with the things she is rightfully controlling in pursuit of her purposes-her property and body. ${ }^{60}$

(2) Rights against persons: These entitle one person to use another person. For instance, your employer gets to use you in pursuit of her purposes. If she uses you, however, she cannot also possess you. You

56. Arthur Ripstein, Force and Freedom: Kant's Legal and Political Philosophy (2009), at $135-136$.

57. DR 6:238, 394.

58. DR 6:260, 412 .

59. See DR 6:270, 421 ("An external object which in terms of its substance belongs to someone is his property (dominium), in which all rights in this thing inhere (as accidents of a substance) and which the owner (dominus) can, accordingly, dispose of as he pleases (ius disponendi de rea sua).").

60. Ripstein, supra note 56, at 66-69. 
must have signed up for the job, and you can always quit. These rights are to performances; to delivery, not title. ${ }^{61}$

(3) Rights to persons akin to rights to things: These entitle one person to possess another. If you are a child, your mother can tell you to eat your vegetables, and you must do it. If your attorney accepts a settlement offer, you did it. They "bind" you by their decisions. However, if they possess you in this manner, they cannot also use you. Whatever decisions they make in respect of you have to be consistent with your purposes, never theirs. It works the other way as well: because they possess you, you can use them. Their "status" in relation to you is an "external object of choice" in your possession, just like a contractual performance owed to you, or a thing in your rightful control. ${ }^{62}$ For the sake of convenience, these are scripted as fiduciary relations. ${ }^{63}$

These basic categories reflect those of delict, contract, and quasiobligation in the Roman law of obligations.

\section{Public Right}

Like the social contract theorists, Kant argues that none of the above relations of private right are secure in a condition of pure private interaction, or "state of nature." However, Kant takes the much more radical position that rights are not just inconvenient or inconclusive in the state of nature, but impossible. Crucially, Kant inverts the order of Grotian and Lockean natural rights theories, which in various ways justify the existence of the state as being for the protection and more efficient enjoyment of full-fledged property rights already existing in the state of nature. Instead, Kant claims that the lawful condition precedes conclusive property rights. ${ }^{64}$ There is no property without law: a peremptory right to use and possess an external thing to the exclusion of all others requires nothing less than the individual consent of everyone in the political community. However, since the (metaphysical, not empirical) process of obtaining such consent would place you at the mercy of everybody, we must instead postulate a political institution capable of expressing the individual consent of all the members of the political community in the form of a single, "omnilateral" will. The particular institution manifesting this omnilateral will is the representative

62. DR 6:247, 402 (enumerating three categories of external objects of choice as "1) a (corporeal) thing external to me; 2) another's choice to perform a specific deed (praestatio); and 3) another's status in relation to me").

63. RipsteIn, supra note 56, at 70-76 (describing "status" relations, of which the "legal relation between a fiduciary and a beneficiary is one such case").

64. DR 6:255-256, 409 ("It is possible to have something external as one's own only in a rightful condition, under an authority giving laws publicly, that is, in a civil condition."). 
legislature. ${ }^{65}$ In other words, the state is not so much "founded" on property rights. Instead, it founds those rights.

The inversions do not stop there: Kant's contract is not "formed" by parties in the state of nature. Instead, it forms those parties. This notion may be explained by contrasting Kant with familiar liberal tenets. On a liberal conception of "negative freedom" or freedom as noninterference, the commands of political authorities are always necessarily restrictions on freedom, even if they ultimately increase the scope of action or the range of interests satisfied. ${ }^{66}$ If, however, freedom is understood as being assured that no other person will dominate or instrumentalize you, then it becomes more obvious that it cannot exist without a set of political institutions authorized to posit your rights in law and enforce them coercively. ${ }^{67}$ Authority is not just compatible with freedom, but necessary for it. ${ }^{68}$ This is why Kant "prefers to speak of an original contract rather than a social contract." ${ }^{69}$ It represents-again conceptually, not empirically ${ }^{70}$ - the choice that makes choosing even possible.

This has two implications. First, in contrast with ordinary private contracts where it is entirely up to the parties whether or not to cooperate, the idea of the original contract envisages forms of cooperation that are mandatory. This is not because the welfare benefits of being in the civil condition are so great that we can presume that you have consented to cooperate. Rather, it is because being in the civil condition is a prerequisite for your even having the capacity to choose. You become free by submitting to authority. If you decline to consent to the original contract, you are choosing to be unfree, which is juridical nonsense, because choosing is only for the free. Rightful honor therefore compels you to choose to join the rightful condition. Alternatively, persons remaining outside the original contract are essentially reserving for themselves the choice to use violence against all others as and when they please. Others need not abide this. Indeed they must not, for they would violate their dignity if they did. ${ }^{71}$ Nor would they wrong you by using violence against you. Outside the original contract you are unfree, and so can be forced-forced to be free.

65. See DR 6:258-259, 411-412.

66. See, e.g., Isaiah Berlin, Two Concepts of Liberty, in Four Essays on LiberTy 118, 123 n.2 (1969) ("Law is always a fetter, even if it protects you from being bound in chains that are heavier than those of the law, say, some more repressive law or custom, or arbitrary despotism or chaos.").

67. DR 6:316, 459 ("One cannot say: the human being in a state has sacrificed a part of his innate outer freedom for the sake of an end, but rather, he has relinquished entirely his wild, lawless freedom in order to find his freedom as such undiminished, in a dependence upon laws, that is, in a rightful condition, since this dependence arises from his own lawgiving will.").

68. DR 6:242, 397 (“... [A] state of nature is not opposed to social but to a civil condition, since there can be society in a state of nature, but no civil society (which secured what is mine by public laws).”).

69. B. Sharon Byrd \& Joachim Hruschka, Kant's Doctrine of Right: A Commentary (2012), at $174-175$.

70. See PP 8:297, 296-297; DR 6:318, 461-462.

71. See PP 8:349, 322; DR 6:307, 452. 
Second, the state is an extension in public right of the idea of a fiduciary in private right. ${ }^{72}$ Because it claims authority over you-that is, the entitlement to determine your legal rights and obligations-the state's powers in respect of you are compatible with dignity only if exercised in a fiduciary capacity. ${ }^{73}$ We saw earlier that Kant describes the republic as the common mother. Kant utilizes precisely the example of parenthood to illustrate the category of rights to persons akin to rights to things. In an argument modeled on negotiorum gestio, Kant argues that parents are obligated to care for their child because they decided to bring it into the world without first obtaining its consent. This obligation of care, however, gives rise to rights against the child: "they also have a right to constrain it to carry out and comply with any of their directions that are not contrary to a possible lawful freedom ..." ${ }^{\prime 4}$ The same rationales of the beneficiary's incapacity to consent, and the fiduciary's obligation of good faith apply in state-subject relations. ${ }^{75}$ Most human beings no more choose their political communities than they select their parents. Moreover, just as a beneficiary requires the intercession of her trustee to enjoy her trust property, neither can an individual enjoy her innate right to freedom without the state.

At this point, another stark difference arises between Kant and other social contractarians, in that the latter tend to conceive of the state as an aggregation of natural persons to celebrate their common sympathies, protect their property rights, ${ }^{76}$ or serve as a clearinghouse mediating between them with respect to their basic needs. ${ }^{77}$ In contrast, Kant pictures the state as a moral person in its own right, with purposes separate and distinct from those of its subjects. This, for instance, is the basis for Kant's remark that extracting reparations from the population of a defeated enemy "would be robbery, since it was not the conquered people who waged the war; rather, the state under whose rule they lived waged the war through

72. See, e.g., Stone v. Mississippi, 101 U.S. 814, 820 (1879) ("The power of governing is a trust committed by the people to the government. . . The people, in their sovereign capacity, have established their agencies for the preservation of the public health and the public morals, and the protection of public and private rights."); Black River Regulating Dist. v. Adirondack League Club, 121 N.E.2d 428, 433 (N.Y. 1984) (“. . . the power conferred by the Legislature is akin to that of a public trust to be exercised not for the benefit or at the will of the trustee but for the common good.").

73. See Paul B. Miller, Justifying Fiduciary Duties, 58 McGill L.J. 969, 1012-1013 (2013) (“[F]iduciary power is not properly understood as connoting relative strength, ability, or influence . . . [but] ought to be understood as a form of authority," or the ability to "render rightful conduct that would otherwise be wrongful.").

74. DR 6:360, 495.

75. See Evan Fox-Decent, Sovereignty's Promise: The State as Fiduciary (2011), at 44-47, 121125 .

76. John Locke, Second Treatise of Government (C.B. Macpherson ed., 1980) (1690), at 64 (ch. $8, \S 120$ ) ("By the same Act therefore, whereby any one unites his Person, which was before free, to any Commonwealth, by the same he unites his Possessions, which were before free, to it also; and they become, both of them, Person and Possession, subject to the Government and Dominion of the Commonwealth, as long as it hath a being.").

77. See, e.g., Henry Shue, Mediating Duties, 98 ETHICs 687 (1988). 
the people...."78 The separate personalities of sovereign and subject is in fact baked into the fiduciary model of authority. States have to be more than just aggregations of subjects because it would otherwise become impossible to judge and criticize the former's treatment of the latter. Any subjects disagreeing with the directives of the state would effectively be contradicting themselves. This is why, in Peter Birks's excellent phrase, fiduciary obligations of competence and disinterestedness are "inseverably compound"; ${ }^{79}$ they contemplate one person taking "positive steps in the interest of another." 80

The distinctness of the state's personality and purposes from those of its subjects is illustrated by Ronald Dworkin's metaphor of an orchestra. An orchestra is more than just an aggregation of individual musicians playing particular notes on particular instruments at particular times. ${ }^{81}$ Moreover, its members "do not suppose that the orchestra also has a sex life, in some way composed of the sexual activities of its members, or that it has headaches, or high blood pressure, or responsibilities of friendship, or crises over whether it should care less about music and take up photography instead." ${ }^{22}$ Instead, the orchestra has just one purpose: making music. Accordingly, the difference between private fiduciaries and sovereigns is that the set of purposes that the latter can act on is much narrower. Private persons can set and pursue private purposes, such as the celebration of religious rituals. States can do no such thing because as public fiduciaries, they have just one public purpose: guaranteeing the equal freedom of the people. ${ }^{83}$ As persons, states also have a natural right to freedom that is unachievable in an international state of nature. Equally, law is not just compatible with the freedom of states, but necessary for it. They too must enter into an international rightful condition.

The distinction between public and private persons gives rise to a second trichotomy of legal categories: that of constitutional, international, and cosmopolitan right. ${ }^{84}$ Unlike the first trichotomy of private right, which represents the possible combinations of possession and use between persons and things, the second trichotomy represents the possible combinations of interactions between public and private persons. Constitutional right covers legal relations (1) between a state and its subjects, and (2) between subjects of the same state. As for international right, Kant departs from both his contemporaries and ours to define it as covering only relations between states. Finally, cosmopolitan right covers legal relations (1) between sovereigns and nonsubjects, and (2) between subjects of different sovereigns. These

78. $D R 6: 348,485$.

79. Peter Birks, The Content of Fiduciary Obligation, 34 Israel L. Rev. 3, 33 (2000).

80. Id. at 37-38 (emphasis added).

81. Ronald Dworkin, Sovereign Virtue: The Theory and Practice of Equality (2000), at 226.

82. Id. at 227.

83. DR 6:318, 461 .

84. DR 6:311, 455 . 
three taken together form the sum total of public right: if any one of these categories is missing, "the framework of all the others is unavoidably undermined and must finally collapse." ${ }^{85}$ Underneath the edifice of public right, however, lie the three basic forms of private right. Because delict, contract, and fiduciary relations represent the three possible ways in which coercion may be used consistently with freedom from domination, their structures are not limited to private law but animate all claims of right, including constitutional law, international law, and cosmopolitan law. ${ }^{86}$

\section{EXPLICATING COSMOPOLITAN RIGHT}

We are now in a position to explore the content of cosmopolitan right and the meaning of hospitality. The scholarly literature divides into two camps. One argues that cosmopolitan right may be explained solely in terms of the innate right to freedom. While not exactly claiming cosmopolitan right to be an acquired right per se, the other camp envisages it nevertheless as a sort of "proto-property" right. This paper agrees with the first camp: cosmopolitan right has nothing to do with property, proto- or otherwise. An innkeeper's obligation of hospitality results not from her ownership of real estate, but from her status as a public fiduciary. The same applies to states. Demonstrating this requires an examination of the concept of the "original common possession of the earth."

A. Common Possession of the Earth's Surface: The Innate Right to Take Up Space

Recall that the refugee is merely an exceptional case for cosmopolitan right. The basic case is that of a visitor who has a state to return to. Recall also that the visitor cannot claim the right to be a guest, because that requires a special pact. All she has is the right to "to present oneself for society." 87 The receiving state can reject her outright; the only thing it cannot do is "punish" the visitor simply for appearing at the border. This right, according to the Perpetual Peace, "belongs to all human beings by virtue of the right of possession in common of the earth's surface on which, as a sphere, they cannot disperse infinitely but must put up with one another; but originally no one had more right than another to be on a place on the earth." ${ }^{88}$ The Doctrine of Right expands on this idea in a passage that bears repeating in full:

[S]ince possession of the land, on which an inhabitant of the earth can live, can be thought only as possession of a part of a determinate whole, and so as

85. Id.

86. Public right contains "no further or other duties of human beings among themselves than can be conceived" at private right. $D R 6: 306,451$.

87. $P$ P 8:358, 329 .

88. Id 
possession of that to which each of them originally has a right, it follows that all nations stand originally in a community of land, though not of rightful community of possession (communio) and so of use of it, or of property in it; instead, they stand in a community of possible physical interaction (commercium), that is, in a thoroughgoing relation of each to all the others of offering to engage in commerce with any other, and each has a right to make this attempt without the other being authorized to behave toward it as an enemy because it has made this attempt. ${ }^{89}$

Cosmopolitan right is "grounded" on original common possession of the earth in this way. What, however, does "grounding" mean? We may illustrate this as follows. Recall that the simplest category of private right is delict, which essentially envisages two free persons interacting as strangers in an arm's-length relation to one another. This rightful relation is disturbed when one party wrongfully interferes with the other's means, in which case an award of damages must be given to restore the original estrangement. ${ }^{90}$ The "interference" does not have to be dramatic or painful: a stranger who merely runs their fingers through your hair is liable to you in battery. Though substantively harmless, she nevertheless commits a civil wrong against you simply because she has formally treated you as a plaything at her disposal, thereby contradicting your innate right manifested as rightful honor. However, that same stranger does you no wrong if she taps you on the shoulder, say, to ask you for directions, or to offer you something for sale. This is because her "use" of your body is for communicating with you, and this is a purpose you simply must share. To deny this would be to presume that anything she might possibly say to you is wrongful, thus literally turning her into an untouchable. This contradicts her innate right, this time expressed as the right to be beyond reproach. Innate right "grounds" acquired rights in this way: it is not itself a legal claim, but it informs and structures legal claims in delict, contract, or unjust enrichment.

The arm's-length relation between the visitor and the receiving state envisaged under cosmopolitan right is similarly structured by deeper, more fundamental entitlements. These are, namely, the visitor's right to make an offer to contract, which the receiving state is entirely free within its innate right to reject. ${ }^{91}$ As the passage from the Doctrine of Right indicates, the right of the visitor not to be treated as an enemy seems to be grounded partly in his innate right of "communicating his thoughts." 92 However, the

89. DR 6:352, 489.

90. Andrew S. Burrows, Understanding the Law of Obligations: Essays on Contract, Tort and Restitution (1998), at 10-11.

91. See PP 8:359, 329-330 (approving the Chinese and Japanese policies of denying or severely restricting entry to European traders). See also Military and Paramilitary Activities in and Against Nicaragua (Nicar. v. U.S.), 1986 I.C.J. 14, If 276 (June 27) ("A State is not bound to continue particular trade relations longer than it sees fit to do so, in the absence of a treaty commitment or other specific legal obligation.").

92. DR 6:238, 394. See also Niesen, supra note 2, at 92. 
passage also focuses closely on the fact that as embodied agents, visitors necessarily occupy space on a planet where space is limited. This gives rise to a right that is innate: it "precedes any acts ... that would constitute rights." ${ }^{93}$

This is explained as follows. The first and crucial point is that your body is not a thing you possess and use to exercise your agency. Instead, your body is your person. Someone who commits a battery against you does not merely wrongfully interfere with your purposes-say, in playing sports. They wrongfully interfere with you. The fact that persons are innately embodied means that they are entitled to take up the particular spot where they happen to be at any particular moment, which by definition cannot be taken up by anyone else. ${ }^{94}$ Seen this way, your "possession" of the ground under your feet is "disjunctive"-it entitles you "neither to authorize anything nor to bind anyone. ${ }^{95}$ All it entitles you to is to remain there for so long as it takes you to remove to some other location. This is reflected in Kant's formulation of the visitor's right as against being treated with hostility so long as he behaves peaceably "where he is." ${ }^{96}$ In the section of the Doctrine of Right specifically dealing with the original acquisition of land, Kant describes it as the right of persons "to be wherever nature or chance (apart from their will) has placed them." 97

These elemental considerations reveal why cosmopolitan right plays a central role in Kant's general theory of law, even though he devotes less than two pages to it. Nevertheless, his anti-colonialism makes him contemplate even this minimal right with distaste. He observes that visits were often accompanied by attempts to establish colonies connected with the mother country, which then provided "the occasion for troubles and acts of violence in one place on our globe to be felt all over it." ${ }^{98}$ Nevertheless, this is as far as he will go: "this possible abuse cannot annul the right of citizens of the world to try to establish community with all and, to this end, to visit all regions of the earth." 99

Up to this point, there is no conceptual difference between the visitor's right to approach the receiving state and her right to approach a private person. The state, like a Roman caupo, has the full discretion whether or not to receive a visitor/guest. This changes once the receiving state figuratively brings the visitor infra hospitium by accepting the visitor's offer to engage in commerce. ${ }^{100}$ It now wields authority over the visitor, who

93. DR 6:262, 415 .

94. Ripstern, supra note 56, at 372 ("Your body enables you to set and pursue purposes in space and time, but you must do so in a way that is consistent with the ability of other embodied rational beings to set and pursue their purposes in time and space.").

95. Id. at 156 .

96. $P P$ 8:358, 329.

97. DR 6:262, 414 .

98. DR 6:353, 489.

99. Id.

100. See Hallman v. Federal Parking Services, 134 A.2d 382, 384 (D.C. 1965), citing Calye's Case, 8 Co. Rep. 32a, 77 Eng. Rep. 520 (1584). 
must obey the laws of the land. As a result, its relationship with the visitor is transformed from delictual or contractual to fiduciary. Not only must the receiving state not itself interfere with the person and property of foreigners through its officials, it must also ensure that the Hausgenosse refrain from the same, and punish them if they do not. The "due diligence" obligations owed by states to other states with respect to the treatment of aliens in their territory can be accounted for in this way. Each state bears a "negative obligation to abstain from directly taking measures (through actions of its own organs) aimed at attacking the security of aliens," as well as a "positive obligation to protect aliens from harmful activities carried out by third persons (private individuals or the organs of other international entities) on its territory," which entails "both an obligation to prevent harmful activities and an obligation, if such activities have occurred, to punish the persons responsible for the wrong suffered by the alien."101

The fiduciary relationship between the receiving state and visitor arises much more quickly—in fact instantly_in the case of a refugee who has nowhere to return to. In such cases, the receiving state's obligation toward the stateless person mirrors its obligations corresponding to its citizens' socioeconomic rights-for instance to adequate housing and foodwhich are grounded not in interests or needs, but in the state's sole purpose of ensuring the equal freedom of all subjects. ${ }^{102} \mathrm{~A}$ homeless person may not sleep on the streets without making a public nuisance of herself. Nor may she sleep on the property of another without committing the wrong of trespass. As such, she is systematically dependent on the kindness of strangers for her occupation of space. If this is not forthcoming, she does wrong simply by standing in one place. Nobody could consent to such conditions consistently with rightful honor, which means that the provision of adequate affordable housing must be a clause of the mandatory contract creating the constitutional order. ${ }^{103}$

$[\mathrm{O}]$ nce the property of a guest is taken into the custody and control of the innkeeper the goods are considered infra hospitium and the liability for loss or destruction of the goods imposed is that of an insurer, unless the property is lost or destroyed by an act of God, the public enemy, or by fault of the guest.

See also StorY, supra note 3, at $312(\$ 478(4))$.

101. Riccardo Pisillo-Mazzeschi, The Due Diligence Rule and the Nature of the International Responsibility of States, 35 German Y.B. Int'L L. 9, 22 (1992). See also Joanna Kulesza, Due DiLigENCE IN INTERNATIONAL LAW (2016), at 224-226.

102. Kant says that the moral obligation to enter into an original contract means the state must provide "the means of sustenance to those who are unable to provide for even their most necessary natural needs." $D R 6: 326,468$. This and the surrounding passages are unusual and differ from the general tenor of his legal theory. Instead, contemporary interpreters largely reconstruct the Kantian argument from more typical freedom-based premises. See, e.g., RIPSTEIN, supra note 56, at ch. 9; Evan Fox-Decent \& Evan J. Criddle, The Fiduciary Constitution of Human Rights, 15 Legal Theory 301, 330-332 (2009); Ernest J. Weinrib, Poverty and Property in Kant's System of Rights, 78 Notre Dame L. Rev. 795, 810-821 (2002).

103. RipsteIn, supra note 56, at 279-281. 
In the same way, a refugee fleeing a war has no rightful condition back home, nor can she settle on the high seas, for these must be kept free to all for travel. Because it would otherwise be inconsistent with innate right, the refugee's offer cannot be understood other than as one seeking to join a rightful condition, which in turn means that it must be met with acceptance. What Kant intends by Untergang is not physical destruction per se, but civil death. ${ }^{104}$ Authority is necessary for freedom, and human beings left without it are destroyed as persons. A receiving state's cosmopolitan obligation, therefore, is not to offer "world citizenship, but [to ensure] the division of the world into states in a way that guarantees that each person has a home state to return to." ${ }^{105}$ This means that if you have no home state, the officials of the receiving state "have to let you stay, simply in your capacity as a citizen of the world." ${ }^{106}$ The receiving state's discretion "runs up against its own internal limit." ${ }^{\prime 107}$ The refugee must be taken in, thus birthing her into the civil life that is hers by innate right.

To illustrate, consider Watson v. Cross, an American authority commonly cited for the rule that innkeepers cannot refuse minors. ${ }^{108}$ In that case, the Kentucky Court of Appeals rejected an attempt by a minor-"infant" in what was then Kentucky judicial parlance-to evade two weeks of hotel charges by arguing that his contract for lodging was invalid for lack of capacity. The court ruled instead that the innkeeper held a valid lien over the plaintiff's goods because he was under an obligation "to receive and entertain all guests apparently responsible and of good conduct, who might come to his house ... and the mere fact of infancy alone in the applicant would not justify him in any such refusal." ${ }^{109}$ As such, simply in virtue of their status as public officials, innkeepers are obligated to enter into obligations with human beings who normally cannot have obligations. The same applies for the public person of the state.

Thus, innate right is really all one needs to elaborate cosmopolitan right on either side of the interaction, both in the ordinary case of visitors with a rightful condition to go back to, and in the exceptional case of refugees with nowhere to go.

B. Rights to an Equal Share of the Earth, Historical Redress, or to Be Somewhere

The opposing view is that accounting for cosmopolitan rights and obligations requires knowledge of further and better "facts about the world." 110

104. This term is used in a different sense than Kant does in his discussion of bankruptcy at DR 6:362, 497.

105. RIPSTEIN, supra note 56, at 297.

106. Id. at 298.

107. $I d$.

108. Watson v. Cross, 63 Ky. (2 Duv.) 147 (1865). See SherRY, supra note 41, at 40-41.

109. 63 Ky. (2 Duv.), at 148.

110. Niesen, supra note 2 , at 90 . 
These may concern questions of resource distribution, historical injustice, or even just geographical specification.

One version of this argument from equal distribution is provided by Peter Niesen, who, in earlier work, argued for the "derivation of cosmopolitan law from acquired rights to property" ${ }^{\prime 11}$ on a view of original common possession as implying some form of equitable distribution of resources. From the premise that "unilateral acquisition obligates individuals and nations towards each other," 112 Niesen observes that the carving up of the world into separate plots and territories "has causally shaped the life chances of our fellow cosmopolitan residents," "113 such that appropriations of territory-even if blameless and not a result of colonial crimes-result "in a distribution of property that can be challenged and will have to be either ratified or corrected in a cosmopolitan condition." 114 Similarly, Claudio Corradetti views the cosmopolitan right to visit "as a limitatory clause to peremptory appropriation, that is, as a generalised guarantee of non-exclusion from territorial accessibility." 115 Corradetti opines that "from the acceptability of an original appropriation ... it follows that those who are excluded by territorial seizure must be compensated through the allocation of a qualified right— the right to visitin order to respect their original right to have a place on earth." ${ }^{116}$ In explaining this compensatory principle, Corradetti refers to the Lockean proviso, according to which enclosures of land in the state of nature are conclusive as long as they ensure "enough, and as good, left in common for others." 117 In contrast, Alice Pinheiro Walla ropes in Grotius, who-as we saw from his reliance on the Aeneid-considers property rights to be defeasible in cases of necessity. From the premise that property is created out of common possession for the greater welfare of human beings, it follows that property rights become defeasible when (1) the thing can be enjoyed by others without any cost to the owner, ${ }^{118}$ or (2) excluding others would result in secular disaster. On these lines, Pinheiro Walla argues that "cosmopolitan right in Kant's theory has a similar function to the right of necessity in Grotius and imperfect rights in Pufendorf's theory." 119

111. Id. at 105 .

112. Id. at 102, citing Katrin Flikschuh, Kant and Modern Political Philosophy (2000), at 152.

113. Niesen, supra note 2 , at 103.

114. Id. at 104 .

115. Claudio Corradetti, Constructivism in Cosmopolitan Law: Kant's Right to Visit, 6 GLOBAL Const. 412, 414 (2017) (citations omitted).

116. Id. at 421.

117. LoCKE, supra note 76, at 19 (ch. 5, §27), cited at Corradetti, supra note 115, at 421-422. 118. Grotius, supra note 19 , at 38 :

If any person should prevent any other from taking fire from his fire or light from his torch, I should accuse him of violating the law of human society. ... Why then, when it can be done without any prejudice to his own interests, will not one person share with another things which are useful to the recipient, and no loss to the giver?

119. Alice Pinheiro Walla, Common Possession of the Earth and Cosmopolitan Right, 107 Kant-STUdien 160, 176 (2016). 
One immediate issue is that these arguments smuggle internal considerations about the substance of choices into Kant's purely formal theory of law. For instance, Niesen considers the protections afforded to voluntary travelers as justified in part on the ethical obligation of peoples not to seclude themselves. ${ }^{120}$ Corradetti for his part tries to avoid such consequentialism by specifying that his reliance on the Lockean proviso "reformulates" it to pay no heed to questions of need. ${ }^{121}$ However, it is difficult to see how this changes anything because leaving behind enough and as good is neither good nor enough to justify excluding others. For Kant, land before original acquisition is not res nullius: ${ }^{122}$ others have just as good a claim to it, which cannot be extinguished by unilateral occupation or specification. If you try to exclude others from a plot of land on the basis that you have labored on it and grown enough apples to feed them, they may justifiably reply that they care not for apples, and-even if they did-that it was not your place to decide that they will have apples. Nor, from the opposite end, does Kant accept a right of necessity. Necessity enters Kant's general theory not as a justification but as a defense, and even then only against criminal rather than civil liability. ${ }^{123}$

The most interesting problem for present purposes, however, lies in the common assumption that territory is akin to property, ${ }^{124}$ which is itself premised on a deeper assumption that "states and peoples . . . take an active part in the process of unilateral appropriation" of their territory. ${ }^{125}$ To wit, it is an obvious empirical fact that political communities discovered, conquered, or stole the land they now have. Metaphysically, however, states do no such thing: they come into existence at the same time as their territory. Territory is not acquired, but innate in the manner of body.

Recall that innateness means being able to say that something is yours independently of any act you did to get it, while acquiredness implies some such act. Your sunglasses are acquired: if someone else had bought them from the shop before you, they could very easily have been hers, not yours. Thus, property has the aspect of being "mine or yours"; ${ }^{126}$ it is

120. Niesen, supra note 2, at 101-102.

121. Corradetti, supra note 115 , at 421.

122. DR 6:265, 417, cited at Corradetti, supra note 115 , at 418 .

123. DR 6:235-236, 391-392 (arguing that to posit a "right of necessity" confuses the possession of a right or "objective impunity" with "subjective impunity").

124. See Pinheiro Walla, supra note 119, at 174 (cosmopolitan right "presents itself under two different modes: (1) as basis of the acquired right of host peoples to their territory, enabling them to decline voluntary interaction ..."); Niesen, supra note 2, at 105 ("[T] he most plausible justification for legal rights and obligations under hospitality lies in their enmeshment with the logic of first appropriation of territorial property."). Niesen has modified this view in subsequent work. See infra note 133.

125. Niesen, supra note 2, at 103. See also Corradetti, supra note 115, at 423 ("[T] he instantiation of a public authority is not only required for the purpose of constraining, under the law, unilateral appropriations of the will through the creation of states, but also in view of compensating, as it were, those subjects who are excluded from such appropriations.”).

126. DR 6:246, 401 . 
by default transmissible because "what is yours might as well be, and might come to be, not only mine, but his, hers, theirs, and so on." 127 Bodies, among other things, are not like this. You do not have to account for how you came to possess it, because if you did not have your present body, there would not have been a you to acquire it. Alternatively, consider that if you and a friend were to exchange all your belongings, your lifestyles would be transformed-perhaps immeasurably-but the two of you could still carry on with the identities you ordinarily present to the world. Not so if you exchanged bodies. Bodies are not "mine or yours," nor are they transmissible. Instead, they are by default inalienable.

All these are also true of territory. Acquiring territory is not something a state can $d o$, because before it has any territory, there is no state to do any acquiring. A state's land holdings may increase through silting or volcanic activity, but this is analogous to you growing a beard or having a heart transplant. Taken as a "totality" - a plurality considered as a unity-the state simply is the territory. ${ }^{128}$ Ruritania and Cagliostro would not simply be altered if they exchanged their territory, natural endowments, and people. They would cease to exist. This is precisely Kant's point in the Second Preliminary Article, which observes that

a state is not (like the land on which it resides) a belonging (patrimonium) ... Like a trunk, it has its own roots; and to annex it to another state as a graft is to do away with its existence as a moral person and to make a moral person into a thing, and so to contradict the idea of the original contract, apart from which no right over a people can be thought. ${ }^{129}$

The distinction Kant seems to draw between the state and its land must not be taken to mean that the territory might be patrimony, even if the state itself is not. While Kant states that title to territory is held by the head of state acting as the "Supreme Proprietor," he defines that function solely as organizing the "division" of land among subjects, and emphatically not as an aggregation of private ownership claims. ${ }^{130}$ The latter would be

127. James Penner, On the Very Idea of Transmissible Rights, in Philosophical Foundations of Property LaW 244, 256 (James Penner \& Henry Smith eds., 2013).

128. On the fundamental reasons disqualifying territory as property, see Arthur Ripstein, Kant and the Law of War (Jun. 28, 2018) (unpublished manuscript, on file with author), at 54-55. Nevertheless, Ripstein resists the conclusion that territory is like body on the grounds that a state's "boundaries may change ... through its own official acts, including wrongful ones," such that "what was once the territory of one state may have become the territory of another." Other reasons are the provisional nature of state possessions in the international state of nature (citing DR 6:350, 487) and the idea that wrongs against bodies involve the subordination of one person's choice to another's, while wrongs against territory involve one legal order being subordinated to another. Ripstein, supra, at 55-56. For brief responses to these points, see text accompanying notes $135-146$.

129. $P P 8: 344,318$.

130. DR 6:323-324, 466 . 
inimical to eternal peace, because, as Kant knew from experience, the patrimonial state generates incessant war. Writing in the wake of the Austrian Wars of Succession and the Seven Years' War-two world wars sparked off by a woman ascending to the Habsburg Throne in violation of ancient Frankish tribal traditions-Kant remarks that

Everyone knows into what danger the presumption that acquisition can take place in this way has brought Europe, the only part of the world in which it is known ... that states can marry each other, partly as a new industry for making oneself predominant by family alliances even without expending one's forces, and partly as a way of extending one's possession of land. ${ }^{131}$

Accordingly, the Second Preliminary Article requires that "No independently existing state (whether small or large) shall be acquired by another state through inheritance, exchange, purchase or donation." Contrary to Derrida, neither the state nor its head can be treated as a master in his own home, for "if the head of state is not a member of the state but is proprietor ... he can decide upon war, as upon a kind of pleasure party ..."132 To treat their territory as property to be bought and sold is to render the human beings on it into things to be bought and sold; in effect, civil death.

In more recent work, Niesen attempts to reconcile notions of territorial redistribution with the inalienability of territory in the rightful international order by means of positing a two-step transition process from a "private" to a "public" international state of nature. ${ }^{133}$ In the private international state of nature, the land of the political community is simply held as the provisional property of the prince. The adoption of the Second and other Preliminary Articles then transforms this land into inalienable territory, but rights in it remain provisional since we are still in a state of nature, albeit now a public one. Only after the adoption of the Definitive Articles is the land confirmed as the peremptory territory of the state in an international rightful condition. In the interim between the two states of nature, Niesen contends that territorial re-assignations should occur in order to reverse territorial transfers contrary to the Second Preliminary Article. In support of this argument, Niesen cites to certain comments about restoring land in the Perpetual Peace, and to the statement in $\$ 61$ of the Doctrine of Right that the external things states "acquire or retain by war" remain provisional outside the

131. $P P$ 8:344, 318.

132. PP 8:351, 324. See also Arthur Ripstein, Just War, Regular War, and Perpetual Peace, 107 KANT-STUdien 179, 188 (2016) ("If states are essentially private and subject to the claims of private right, disputes about them will multiply, and war becomes a means of acquisition.").

133. See Peter Niesen, Restorative Justice in International and Cosmopolitan Law, in KANT AND Colonialism: Historical and Critical Perspectives 170 (Katrin Flikschuh \& Lea Ypi eds., 2014); Peter Niesen, "What Kant Would Have Said in the Refugee Crisis", 50 Danish Y.B. PhIL. 83, 91-96 (2017). 
international rightful condition. ${ }^{134}$ On this basis, he argues that cosmopolitan right incorporates not just considerations of fair resource distribution, but also the reversal of historical wrongs.

As an ethical matter, the attraction of Niesen's argument is obvious: the fact that a foreigner comes from a country that was previously dominated or is currently being exploited by the receiving state must weigh significantly in the use of administrative and legislative discretion as to whether to issue her a visa, or perhaps to extend her voting rights and citizenship. As a legal matter, however, these factors seem irrelevant: it is hard to see how a refugee's right to be taken in could be less weighty if she came from a country not previously oppressed by that state. Of course, the refugee's claim may appear "more" weighty if she did come from such a country, but what more weight would you need? Besides, the comment about restoring land features in the course of a discussion of the spurious excuses a monarch might offer to put off the adoption of the Preliminary Articles indefinitely. ${ }^{135}$ However, incorporating the reversal of historical wrongs into the concept of cosmopolitan right-a Definitive Article-would have precisely this effect. Every encounter with a foreigner would involve the re-litigation of historical grievances, an endless reopening of ancient wounds making peace forever unachievable.

Secondly, provisionality goes to the stability or security of a right while alienability pertains to its content: a right can be inalienable yet precarious. Kant envisions the land of "savages"-arguably the prime exemplars of a private international state of nature-in precisely this way. He specifically denies the application of the Lockean proviso to indigenous peoples in his statement that while colonies may be established on land truly far away from them, they are not allowed if the "people are like shepherds or hunters ... who depend for their sustenance on great open regions ..."136 The reason, it is submitted, is because even though such peoples do wrong in the highest degree by remaining outside a rightful condition, others are in no position to hold this against them. As Ripstein puts it, "whatever uncertainty there is with respect to who may act on behalf of this people, the visitor must accept that the visitor itself is not so charged, and so must not take it upon itself to make arrangements for the inhabitants." ${ }^{137}$ A people's land is not to be treated

134. PP 8:347, 321; DR 6:350, 487. Discussed in Niesen, What Kant Would Have Said, supra note 133 , at 95 .

135. PP 8:347, 321 (“ $[\mathrm{H}]$ e may not postpone to a nonexistent date (ad calendas graecas, as Augustus used to promise) putting into effect the law, for example, to restore in accordance with number 2 the freedom of certain states deprived of it, and so not restore it. . ..").

136. DR 6:354, 490. Contrast this with Locke's infamous claim that all persons have a right to terra nullius — defined broadly as not just unoccupied but also uncultivated land. LockE, supra note 76, at 21-23 (ch. 5, §§32, 36).

137. Arthur Ripstein, Kant's Juridical Theory of Colonialism, in Kant and Colonialism: Historical and Critical Perspectives 145, 165 (Katrin Flikschuh \& Lea Ypi eds., 2014). See also Martin Ajei \& Katrin Flikschuh, Colonial Mentality: Kant's Hospitality Right Then and Now, in KanT AND Colonialism: Historical and Critical Perspectives 221, 246 (Katrin Flikschuh \& Lea Ypi eds., 2014): 
as contingent transferrable property just because they lack a republican constitution.

Interestingly, Kant goes on to say that a settlement may be established with uncivilized peoples by contract, but specifies that such a contract must "not take advantage of the ignorance of those inhabitants with respect to ceding their lands." ${ }^{138}$ As we have seen, Kant envisages a spectrum of contracts ranging from mandatory to prohibited. Ordinarily, however, contracts are by default voluntary, and their validity does not depend on the reasons why they were entered into. It may be idiotic to sell your Maserati for a peppercorn, but you have the right to make such an offer, and the obligation to deliver if someone accepts. A settlement contract with native peoples is evidently not an ordinary contract for buying and selling property. Instead, its onerous requirement of informed consent is reminiscent of the curious passages in the Doctrine of Right concerning sexual intercourse. In these, Kant begins by observing that because a "human being cannot have property in himself, much less in another person," it follows that intercourse for mere carnal enjoyment constitutes "cannibalistic . . . use by each of the sexual organs of another ..." ${ }^{139}$ Such use of another's body makes each participant "a consumable thing (res fungibilis) with respect to the other, so that if one were to make oneself such a thing by contract, the contract would be contrary to law." ${ }^{40}$ While the legal systems the reader may be familiar with hopefully do not follow this rationale fully, it nevertheless informs laws concerning sex work and other bodily alienations such as organ transplantation and euthanasia. These are often prohibited, or if allowed, not on commercial terms. If they are permitted commercially, efforts are made to ensure that such activity is the result of genuine and informed choice rather than vulnerability and exploitation. Kant applies the same logic to the territory of a people-civilized or savage-because it is akin to the body of their state.

Again, Kant's ideas find illustration in the evolution of the international law of territory. While early case law allowed for "acquisitive prescription" of territory through effectivités (effective administration) by explicit analogy to the prescription of land in municipal law, ${ }^{141}$ current practice is the polar opposite, allowing transfers of territorial sovereignty only with the positive acquiescence of the transferor. ${ }^{142}$ The rationale behind the new rule is

For all [visitors] know, stateless peoples do in fact possess political institutions. . . This stance expresses an epistemic modesty against which the cautiously formulated right to attempt contact makes good sense. In our dealings with distant strangers ... [w] e should accept that they are agents in their own right, with reasons for action, about which we are likely to know and understand very little.

138. $D R 6: 354,490$.

139. DR 6:359, 494-495. On the rule that no free man can be viewed as owning his limbs, see Dig. 9.2.13.8 (Ulpian, Ad Edictum 18).

140. DR 6:359-360, 495.

141. Island of Palmas (Neth./U.S.), 2 R.I.A.A. 829, 867-869 (Perm. Ct. Arb. 1928).

142. Frontier Dispute (Burk. Faso v. Mali), 1986 I.C.J. 554, II 63-67 (Dec. 22); Land, Island and Maritime Frontier Dispute (El Sal. v. Hond.; Nicar. intervening), 1992 I.C.J. 351, III 223- 
peace: no matter how poorly drawn by former colonial powers, existing borders must be respected in order "to prevent the independence and stability of new States being endangered by fratricidal struggles provoked by the challenging of frontiers. ..."143 For similar reasons, the World Court has twice rejected "Lockean proviso"-style arguments for borders to be adjusted in order to effect more equitable distributions of natural resources. ${ }^{144}$ Finally, ample evidence of the civil destruction of human beings is provided by past and present practices of acquiring or holding territories by purchase, grants in perpetuity, lease, international mandate, and condominia. ${ }^{145}$ New Hebrideans used to joke that the former system of British-French joint rule of their islands was not so much a condominium but pandemonium, ${ }^{146}$ while the leased territories that still exist todaythink of Guantánamo Bay and Diego Garcia-are primarily known for lawlessness, torture, and mass dispossession.

According to a recent study by Madeline Gleeson, it would appear that much the same can be said about "offshore" Refugee Processing Centres (RPCs) set up in Nauru and Papua New Guinea under the current Australian government's asylum policy. Gleeson's account paints a picture of these places as carefully constructed states of nature: administrative procedures are deliberately designed to ensure that "it would never be entirely clear who was really making the decisions," ${ }^{147}$ which is obviously ideal for deflecting scrutiny into conditions in the camps, or for denying responsibility for the harrowing stories of abuse and self-mutilation. ${ }^{148}$ At various points, Gleeson describes the countries hosting the RPCs using asylum seekers as bartering chips in exchange for developmental aid. ${ }^{149}$ Finally, there is the suggestion of the corruption of the body politic: she quotes a statement by the Greens Senator Christine Milne to the effect that competing to be more unattractive than the circumstances from which refugees are running from only ends with the national political discourse "becoming crueller and

224 (Sept. 11). However, the standards for acquiescence can be quite lax. In Pedra Branca the court held that sovereignty over a disputed island had passed from Malaysia to Singapore effectively by silence. Sovereignty over Pedra Branca/Pulau Batu Puteh, Middle Rocks and South Ledge, (Malay. v. Sing.) 2008 I.C.J. 12, II 121 (May 23).

143. Frontier Dispute, 1986 I.C.J., at If 20.

144. Continental Shelf (Tunis. v. Libya), 1982 I.C.J. 473, II 107 (Feb. 24); Land, Island and Maritime Frontier Dispute, 1992 I.C.J., III 40, 57-58.

145. Hersch Lauterpacht, Property Relations Between States. State Territory, in InTERnational LaW: Volume 1, The General Works: Being the Collected Papers of Hersch Lauterpacht 367, 370 (Eli Lauterpacht ed., 1970).

146. Michelle Bennett \& Jocelyn Harewood, Vanuatu (2003), at 14.

147. Madeline Gleeson, Offshore: Behind the Wire on Manus and Nauru (2016), at 28 (ch. 5 ).

148. The author was herself unable to visit the RPCs personally. A running theme of the book is her being sent from pillar to post by the different state authorities claiming that someone else was in charge.

149. GleEson, supra note 147, at 25 ("Refugees could be a resource too, the small nation [Nauru] would soon discover. . . . Despite the MOU's emphasis on 'joint cooperation' to combat people smuggling, it was a commercial transaction - not a regional responsibility-sharing arrangement."). 
crueller and crueller ..."150 However, if a refugee's right was primarily about having a fungible share of the earth's land-a "right to be somewhere"-what exactly would be the principled objection against offshore RPCs? After all, if cosmopolitan right was a matter of compensating for inequities in land shares arising from original appropriation or for meeting the demands of necessity, what would it matter if the land offered was located here, there, or in Nauru?

In a recent piece, Jakob Huber purports to identify a difficulty with the argument from pure innate right advocated here, on the grounds that if original common possession is a "right to be granted a place somewhere on the earth such that the conditions of agency are fulfilled," it simply cannot be an innate right. ${ }^{151}$ Rather, it would have to be an acquired right displaying the "mine and yours" quality, because "somewhere" could be here or there. From the other direction, Niesen argues that the right against being treated with hostility cannot be accounted for purely as a matter of innate right, because in most claims of cosmopolitan right, "making contact is typically based on choice." ${ }^{152}$ Traders, tourists, and traveling dance troupes could very well have gone there rather than come here.

The first response to these claims is that the "right to be somewhere" is not how Kant puts it. Instead, he speaks of a visitor's right to be "where he is," or where nature or chance, apart from his will, has placed him. This is not a right to some spot on earth, but to the spot where you are right now, which is just where you cannot help but be. Considered in this way, the ground beneath your feet becomes as inseparable from you as your shadow. This elemental fact structures the forms of coercive interactions you can have with other persons. This brings us to Niesen's argument about the rights of voluntary visitors requiring more than innate right. Imagine that somebody invites you to a party at her country house, and you freely choose to accept. On the day, you arrive at the gate and the footman ushers you in. However, just as you are hanging up your coat, your host changes her mind and orders you out of her house. This is most unwelcoming but, as we saw earlier, wholly within her right, such that you wrong her in trespass if you stay. Nevertheless, you still have a bare license to remain on the property for so long as it takes you to pick yourself up, take your coat, walk through the portico, down the driveway, and so on, simply because as an embodied being, you cannot instantaneously teleport yourself away.

This point is somewhat occluded in English law, where trespasses are often described as violations of property rights actionable per se-that is, the instant you set foot on another's land even if you do so under an

151. Jakob Huber, Cosmopolitanism for Earth Dwellers: Kant on the Right to Be Somewhere, 22 Kantian Rev. 1, 8 (2017). See also Byrd \& Hruschka, supra note 69, at 128 ("The place I have a right to be is not any permanent place, but rather some place or other on the earth. The right to a place on the earth is thus not a right to a specific place, but a right to some place.").

152. Niesen, supra note 2, at 102. 
innocent mistake. ${ }^{153}$ Nevertheless, liability is not strict: trespass does not lie if you were involuntarily dropped onto the plaintiff's land by another, ${ }^{154}$ or if you traversed it because the public roads were flooded. ${ }^{155}$ You may not be held liable for simply being there. This principle is exhibited more clearly in the Roman law, where trespasses are considered objectionable as invasions of privacy; that is, as outrages of rights in personality. You do not wrong another simply by wandering into their land. If they tell you to leave, you must do so within reasonable delay. You wrong them only if you stick around beyond this, because this expresses contempt for their dignitas as the owner of their land. ${ }^{156}$

In this way, a voluntary visitor may not be treated with hostility simply because she is there. ${ }^{157}$ She is entitled to this because her person exists in space. In essence, hers is not a claim in vindicatio to a thing (a place), but in condictio to a standard of treatment (to be allowed to remain in her place until she can remove herself). That standard is hospitality, and the obligation it connotes is personal. States may not contract away their obligations to others, ${ }^{158}$ because their status as public fiduciaries is as much part of their person as their body or reputation. ${ }^{159}$ An innkeeper cannot refuse a traveler even if there are other "separate and equal" establishments nearby. Likewise, a receiving state may not outsource its obligations of asylum any

153. See Entick v. Carrington, (1765) Howell's St. Tr. 1029, 1066 (K.B.) (Eng.) ("By the laws of England every invasion of private property, be it ever so minute, is a trespass."); Basely v. Clarkson (1681) 3 Lev. 37 (Eng.) (plaintiff given judgment for two shillings against adjoining neighbor who mistakenly mowed grass on plaintiff's land); Severn Trent Water Ltd v. Barnes [2004] EWCA (Civ) 570, II 5 (Eng.) (damages awarded for "trivial, accidental and unintentional" entry onto land).

154. Smith v. Stone (1647) Sty. 65 (Eng.).

155. Taylor v. Whitehead (1781) 99 Eng. Rep. 475 (K.B.) (Eng.).

156. See David L. Carey Miller, Public Access to Private Land in Scotland, 15 Potchefstroom Electronic L.J. / Potchefstroomse Elektroniese Regsblad 119, 120 (2012) (“. . . [T] he landowner has an enforceable right to require a trespasser to leave but there is no civil claim for the act of trespass per se as there is, on the basis of the 'tort of trespass,' in English law."); William W. Buckland \& Arnold D. McNair, Roman LaW and Common LaW: A Comparison in Outline (2d ed. 1965), at 102 (trespass actionable in Roman law only if the owner "had expressly forbidden entry or if it was an enclosure, such as a dwelling-house, into which everyone knew that free entry would be forbidden. ...").

157. See DPP 23:172-173:

So erkennt der beduinische Araber bey einem vor seinem Zelt sich einfindenden Fremden die Pflicht der Wirthbarkeit selbst wenn er nach dem friedlichen Empfang ihn von sich abweiset. Auf diese Wirthbarkeit kann der Fremdling Anspruch machen (nicht aber auf ein Gastrecht als wozu ihn sein Wirth besonders einladen müßte) als auf ein Besuchsrecht welches allen Menschen vermöge der Freyheit des ihnen von der Natur angewiesenen Raumes zukommt.

In the published version, Kant removes these approving remarks about the Bedouins and turns them into exemplars of Unwirtbarkeit who regard every "approach to nomadic tribes as a right to plunder them." PP 8:358, 329 .

158. Dig. 49.1.4.5 (MACER 1, De Appellationibas) ("Procuratorem alium procuratorem facere non posse."). An equivalent common law maxim is delegata potestas non potest delegare.

159. Dig. 47.10.1.2 (Ulpian, Ad Edictum 56). See also DR 6:328-329, 470-471. 
more than it may prostitute its territory or sell its people. The reason why one state may not offshore its asylum obligations is the same reason why another may not onshore them.

\section{CONCLUSION}

Explaining cosmopolitan right by analogy to the private law of innkeeping helps clear up some mysteries. First, when Kant says cosmopolitan right has nothing to do with philanthropy, he means it. Second, Kantian hospitality entails onerous public, fiduciary obligations that no private person can or should ever bear. Third, the cosmopolitan obligations of receiving states have nothing to do with acquisition or ownership of property, but obtain solely in virtue of their public role and the form of relationship vis-à-vis any particular visitor. Where the visitor is peaceable, capable of supporting herself, and able to return to her own political community, all that she has a right to is to present herself for society. Where the visitor does not have a political community, such that turning her away would bring about her civil death, the receiving state must let her stay simply so she can rightfully occupy the spot on earth where she cannot help but be. 